\title{
Plant-derived VLP: a worthy platform to produce vaccine against SARS-CoV-2
}

\author{
Farshad Hemmati - Mohsen Hemmati-Dinarvand • Marziye Karimzade • \\ Daria Rutkowska • Mohammad Hadi Eskandari • Sayyad Khanizadeh • \\ Alireza Afsharifar
}

Received: 25 March 2021 / Accepted: 10 November 2021 / Published online: 27 November 2021

(C) The Author(s), under exclusive licence to Springer Nature B.V. 2021

\begin{abstract}
After its emergence in late 2019 SARSCoV-2 was declared a pandemic by the World Health Organization on 11 March 2020 and has claimed more than 2.8 million lives. There has been a massive global effort to develop vaccines against SARS-CoV-2 and the rapid and low cost production of large quantities of vaccine is urgently needed to ensure adequate supply to both developed and developing countries. Viruslike particles (VLPs) are composed of viral antigens that self-assemble into structures that mimic the structure of native viruses but lack the viral genome. Thus they are not only a safer alternative to attenuated or inactivated vaccines but are also able to induce potent cellular and humoral immune responses and can be manufactured recombinantly in expression systems that do not require viral replication. VLPs
\end{abstract}

F. Hemmati $(\bowtie) \cdot$ A. Afsharifar $(\square)$

Plant Virology Research Center, College of Agriculture,

Shiraz University, Shiraz, Iran

e-mail: f.hemati@shirazu.ac.ir

A. Afsharifar

e-mail: afsharifar@shirazu.ac.ir

M. Hemmati-Dinarvand

Department of Clinical Biochemistry, School of

Medicine, Shiraz University of Medical Sciences, Shiraz,

Iran

M. Karimzade

Plant Pathology Department, Faculty of Agriculture,

Tarbiat Modares University, Tehran, Iran have successfully been produced in bacteria, yeast, insect and mammalian cell cultures, each production platform with its own advantages and limitations. Plants offer a number of advantages in one production platform, including proper eukaryotic protein modification and assembly, increased safety, low cost, high scalability as well as rapid production speed, a critical factor needed to control outbreaks of potential pandemics. Plant-based VLP-based viral vaccines currently in clinical trials include, amongst others, Hepatitis B virus, Influenza virus and SARS-CoV-2 vaccines. Here we discuss the importance of plants as a next generation expression system for the fast, scalable and low cost production of VLP-based vaccines.

D. Rutkowska

CSIR Next Generation Health,

PO Box 395, Pretoria 0001, South Africa

M. H. Eskandari

Department of Food Science and Technology, College of

Agriculture, Shiraz University, Shiraz, Iran

S. Khanizadeh

Hepatitis Research Center, Lorestan University of

Medical Sciences, Khorramabad, Iran 
Keywords Virus-like particle - VLP - Vaccine . Plant-based $\cdot$ SARS-CoV-2 $\cdot$ Coronavirus $\cdot$ Expression

\section{Introduction}

Coronaviruses (CoVs) are a major group of viruses belonging to the family Coronaviridae that cause a wide spectrum of diseases. The early twenty-first century has experienced the unprecedented spread of previously unknown, deadly coronaviruses (Song et al. 2019). CoVs infect the gastrointestinal, respiratory, hepatic, and central nervous systems of humans, birds, livestock, mouse, bat, and many other wild animals (Chen and Guo 2016; Ge et al. 2013; Wang et al. 2006).

SARS-CoV emerged as a new human infection in South China in November 2002 and ended in July 2003. It infected 8096 people and caused 774 deaths with an overall mortality rate of about $9.6 \%$ (Drosten et al. 2003; Ksiazek et al. 2003). MERS-CoV, another highly pathogenic CoV, first emerged in Saudi Arabia, caused a total of 2494 laboratory-confirmed cases of infection and 858 deaths in 27 countries (mortality rate, 34.4\%) since September 2012 (http://www.who. int/emergencies/mers-cov/en/) (Hemida 2020). These two highly pathogenic betacoronaviruses ( $\beta$-CoVs) have posed a substantial threat to public health (Han et al. 2020). Severe acute respiratory syndrome coronavirus 2 (SARS-CoV-2) emerged from China in December 2019 and has since been reported all over the world with more than $124,000,000$ confirmed cases and 2,730,000 deaths up to 22 March 2021 (https://www.who.int/emergencies/diseases/novelcoronavirus-2019/situation-reports/; https://www. worldometers.info/coronavirus/). (Hemmati et al. 2020). In comparison with the H1N1 Influenza virus that has a $0.02 \%$ mortality rate, SARS-CoV-2 has a mortality rate of 3\% (Rosales-Mendoza 2020). A number of therapeutic options for the treatment of SARS-CoV-2 have been proposed ( $\mathrm{Li}$ and Clercq 2020) however, vaccination remains one of the most effective strategies in the prevention of new coronavirus virus epidemics (He and Jiang 2005).

SARS-CoV-2 is an enveloped, positive-sense, single-stranded linear RNA betacoronavirus with a genome ranging from 26 to $32 \mathrm{~kb}$ in length (the largest viral RNA genome known) (Armbruster et al. 2019). Similar to SARS and MERS, the SARS-CoV-2 genome encodes structural proteins [e.g., spike glycoprotein (S)], non-structural proteins (e.g., 3-chymotrypsin-like protease, papain-like protease, helicase, and RNA-dependent RNA polymerase), and accessory proteins. These five proteins were recognized as attractive targets for developing vaccines and other antiviral agents against SARS and MERS (Fehr and Perlman 2015; Han et al. 2020; Li et al. 2020; Malik et al. 2020). The spike glycoprotein ( $\mathrm{S}$ ) forms homotrimers that are presented on the surface of the virion resulting in the typical coronavirus crown-like appearance. This $\mathrm{S}$ protein is indispensable for virus-cell receptor interactions during viral entry (Mahmood et al. 2021; Zumla et al. 2016) and is the major antigen capable of eliciting protective immune responses (Du et al. 2009; Gralinski and Menachery 2020). It is therefore not surprising that the $\mathrm{S}$ protein has been the most appealing target protein included in the 12 vaccines that have received authorization for use in at least one region (Funk et al. 2021). Among these are a lipid nanoparticle-encapsulated mRNA vaccine and recombinant adenovirus-vectored vaccine expressing the S protein (Folegatti et al. 2020; Mulligan et al. 2020). Subunit vaccines containing individual SARS-CoV-2 antigens as well as viruslike particle (VLP)-based vaccines presenting antigens in multiarrays on their surfaces are also being developed and are being tested in clinical trials (Capell et al. 2020; Ward et al. 2020; Palca 2020, Novavax.com,). The recent emergence of neutralization-resistance SARS-CoV-2 variants (Williams and Burgers 2021) necessitate the employment of vaccine expression systems that allow for the rapid production of relevant vaccines at a low-cost ensuring vaccine availability to even resource constrained developing countries (Fuenmayor et al. 2017; Giddings 2001; Loh et al. 2017; Twyman et al. 2003).

\section{Virus-like particles (VLPs) as vaccine candidates}

Virus-like particles (VLPs) are self-assembled structures from viral antigens that mimic the three-dimensional, morphological structure of virions but lack the viral genome (Grgacic and Anderson 2006; Kushnir et al. 2012). Due to their similarity with the native 
virion in terms of size, shape, and the repetitive array of immunogenic epitopes displayed on the VLP surface, VLPs, like native virions, can induce potent cellular and humoral immune responses without adjuvant (Bachmann and Jennings 2010; Chackerian 2007; Ge et al. 2013; López-Macías 2012; Roldao et al. 2010). Due to particulate nature and size, VLPs interact and are taken up by dendritic cells (DC's) and which then process and present the thousands of epitopes a single VLP contains on MHC class I/II molecules inducing a potent $\mathrm{T}$-cell mediated immune responses (Chackerian 2007; Roldao et al. 2010). The high density display of epitopes in repetitive arrays on the surface of VLPs are also able to elicit high titre and durable B-cell immune responses in the absence of adjuvants (Bachmann et al. 1993; Fehr et al. 1998).

VLPs also present a safer alternative to the current generation of live, attenuated or inactivated vaccines due to their lack of viral nucleic acid and are thus noninfectious (Marsian and Lomonossoff 2016). In addition, antigens being presented in their native conformation on the surface of a VLP are more stable than in a subunit form resulting in smaller and less frequent doses of the antigen required to elicit a protective immune response (Chen and Lai 2013).

The intrinsic characteristics of VLPs have made them into one of the most successful recombinant vaccine platforms. VLP-based vaccines that have been approved by regulatory agencies and are available on the commercial market include those against human papillomavirus virus (HPV) (Cervarix $^{\mathrm{TM}}$ by GlaxoSmithKline and Gardasil ${ }^{\circledR}$ and Gardasil ${ }^{\circledR}$ by Merck), composed of the HPV major capsid protein L1, and against hepatitis B virus (HBV) (Energix ${ }^{\circledR}$ GlaxoSmithKline and Recombivax ${ }^{\circledR}$ by Merck) composed of hepatitis B surface antigen (HBsAg). These vaccines have been shown to be highly effective and safe in humans and capable of inducing long-lasting humoral immune responses These vaccines can induce long-lasting immune responses due to the induction of antibodies that are highly effective and safety profiles in humans (Chackerian 2007; Ge et al. 2013). These successes have encouraged the development of VLPbased vaccines against a wide variety of other diseases. However, the high costs associated with the yeast and insect cell expression systems that produce the HPV and HBV vaccines preclude the widescale use of these vaccines in developing countries (Waheed et al. 2012).

\section{VLP production platforms, including plants}

Current VLP expression platforms include bacterial, yeast, insect, mammalian cell culture and more recently, plants, with the yeast, insect and mammalian systems used for commercial production (Chen and Lai 2013). Each system has its unique advantages and limitations and the choice of platform is usually dependent on the structure and function of the VLPs produced, the scalability and cost of the production process (Gecchele et al. 2015). The use of Escherichia coli bacteria is widespread due its rapid growth rate and simplicity, which allows recombinant proteins to be produced in less than a day. However, the inability to perform glycosylation and other post-translational protein modifications which are critical in the correct protein folding and assembly of VLPs preclude the use of bacterial expression for VLPs (Edman et al. 1981; Ma et al. 2005; Yao et al. 2015). The presence of bacterial endotoxins that require removal post production is also a major drawback. In yeast cells glycosylation is mostly limited to inconsistent high mannose glycoforms (Wildt and Gerngross 2005) which is not optimal for the assembly of many VLPs. The simple post translational modifications (high mannose glycosylation), as well as coproduction of baculovirus particles, are limitations of the insect cell expression system (Chen and Lai 2013; Demain and Vaishnav 2009; Loh et al. 2017). The most optimal environment for authentic post-translational protein modifications and correct VLP assembly are mammalian cell cultures. However, significant capital investment to set up a manufacturing facility, significantly higher production costs and well as contaminating adventitious human pathogens in the cultures are significant drawbacks to this production system (Chen 2008). Indeed, all cell-culture-based production systems require the building of new facilities and fermentation tanks for large scale production creating challenges in scalability. Plants, however, are inexpensive to grow on a large scale in greenhouses or bioreactors, and have been investigated for the last 20 years for the production of therapeutics for humans and animals (Lico et al. 2008; Ma et al. 2003; Twyman et al. 2003).

Current plant expression systems enable the production of large quantities of recombinant protein with post-translational modifications allowing for VLP assembly, at low cost and at low risk of introducing 
adventitious human pathogens (Faye and Gomord 2010). Early attempts at VLP production in plants had several drawbacks including low yields and a very slow production process which involved the production of stable transgenic plants (Davies 2010). The recent development of plant virus-based transient expression systems, depicted in Fig. 1, have greatly increased VLP production speed and yield (Marsian and Lomonossoff 2016).

Deconstructed viral vectors, based on Tobacco Mosaic virus (TMV), the Cowpea Mosaic virus (CPMV), Potato virus $\mathrm{X}$ and Bean yellow dwarf geminivirus, are delivered into plants by Agrobacterium allowing for the fast expression of recombinant proteins at high yields and allowing for highly scalable, GMP-complying industrial processes (Salazar-González et al. 2015). The TMV RNA replicon (the Magnicon) system (Huang et al. 2009), CPMV RNA replicon (the pEAQ) system (Sainsbury and Lomonossoff 2008) and the geminiviral DNA replicon system based on bean yellow dwarf virus (BeYDV) (Santi et al. 2008) are popular transient expression systems that could be used for the rapid expression and assembly of VLP vaccines against viruses that mutate their surface antigens rapidly, like coronaviruses.

$\mathrm{N}$-glycosylation of proteins in plants is similar to that in mammalian cells however, plant-specific $\beta-1,2-$ xylose and core $\alpha-1,3$-fucose residues are added to complex $\mathrm{N}$-linked glycans and no terminal $\beta 1,4$-gal and $\mathrm{N}$-acetylneuraminic acid (Neu5Ac) residues are added (Gomord et al. 2010). These minor differences between plant and mammalian cell protein glycosylation were previously thought to be capable of reducing efficacy of plant-produced vaccines and/or eliciting allergic adverse side-effects in immunized individuals (Chen and Lai 2013). Recent studies in 14,000 people immunized with plant-derived influenza vaccine candidates indicate no allergic-type reaction to these plant-produced influenza VLPs presenting plant glycosylation (Ward et al. 2014). Plant-specific glycosylation thus does not interfere with the proper folding and assembly of the influenza VLPs which are also immunogenic. 'Humanized' plant lines, which have been genetically modified to eliminate plant-specific glycans and/or introduce mammalian-specific glycosylation, produce proteins with specific mammalian glycoforms including high mannose, GnGn, G0-G2 galactose, bisected GlcNAc, fucosylated and nonfucosylated and terminal sialic acid addition with a high degree of glycan uniformity (Castilho et al. 2011, 2008, 2010; Cox et al. 2006; Gomord et al. 2010; Schähs et al. 2007; Strasser et al. 2009, 2008).

Advantages of the current plant transient expression systems are thus appropriate glycosylation of the expressed proteins resulting in proper folding and assembly of VLPs, rapid rate of protein production, high protein yields, high scalability, low cost and increased safety due to the low risk of adventitious
Fig. 1 Schematic review of recombinant protein expression in plants. $V L P$ Virus-like particle, a Recombinant vector construction,

b Agroinfiltration in plants, c 3-7 days post-infiltration recombinant proteins are expressed in the leaves, and VLP subunits assembled into VLPs displaying epitope on the surface, and d VLPs are purified and used as a vaccine to induce immune responses

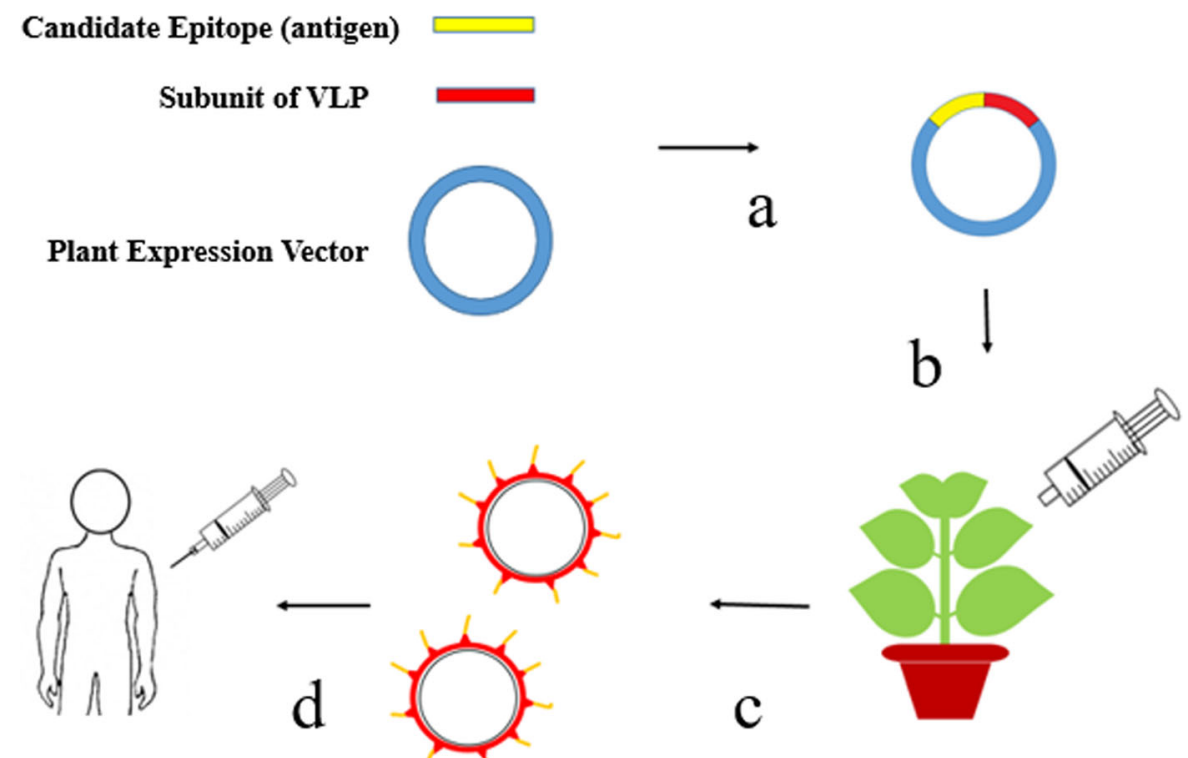


human pathogens (Chen and Lai 2013). Unlike other expression systems, a plant-based system does not require expensive equipment for start-up and operation so that the cost of production based on the plant system has reduced to $0.1 \%$ of the mammalian cell culture system and $2-10 \%$ of microbial systems (Yao et al. 2015). Plants are photoautotrophs, easy to grow, and require no advanced equipment, thus they can be easily cultivated and produced in large numbers. Moreover, plants can make complex proteins with structures that are naturally similar to spider silk, collagen, and secretory immunoglobulin A (Tschofen et al. 2016). Moreover, plants are free of endotoxins, oncogenes, and mammalian pathogens, therefore, they are safe and exempt from the costs of refinement and product screening. More than 25 plant-expressed pharmaceuticals have been developed and evaluated in the clinical trials (Loh et al. 2017). It is thus not surprising that commercial companies have successfully developed a number of plant-expressed pharmaceutical vaccines and therapeutics (Table 1).

\section{Plant-produced VLPs as vaccine candidates}

Several VLPs have been developed as vaccine candidates in plants since plant expression systems were introduced. Hepatitis B virus (HBV), human papillomavirus (HPV), influenza virus, SARS-CoV-2, Norwalk virus, human immunodeficiency virus, foot-andmouth disease virus, Rotaviruses, Bluetongue virus, and hepatitis $\mathrm{C}$ virus VLPs have all been assembled as vaccines in plants (C Thuenemann et al. 2013; D'Aoust et al. 2008; Mason et al. 1996; Meyers et al. 2008; Pan et al. 2008; Saldaña et al. 2006; Santos et al. 2005; Scotti et al. 2009; Ward et al. 2021). In this review we will discuss in detail the plant-produced vaccines against HBV, HPV, Influenza and SARSCoV-2.

\section{HBV}

HBV VLPs have been widely studied in the last two decades. HBV VLPs were first assembled in yeast in 1984 and induced a good immune response as a vaccine candidate (McAleer et al. 1992). Two commercial vaccines, Recombivax ${ }^{\circledR}$ and Energix ${ }^{\circledR}$, based on HBV VLPs, are produced in yeast expression systems. Arntzen's group first demonstrated the possibility of producing VLPs in plants in 1992. They expressed the hepatitis B core antigen $(\mathrm{HBcAg}$ ) in tobacco and assembled 22-nm HBV VLPs capable of inducing an immune response in mice (Mason et al. 1992; Thanavala et al. 1995). More recently, HBV VLPs have been generated through the expression of $\mathrm{HBcAg}$ in transient expression systems mediated by expression vectors such as pEAQ in Nicotiana benthamiana plants (Huang et al. 2006; Mechtcheriakova et al. 2006; Peyret et al. 2019; Peyret and Lomonossoff 2013). These VLPs are morphologically and immunogenically quite similar to yeast- or E. coliderived HBV VLPs (Huang et al. 2006).

Due to their particulate nature and ability to display epitopes on their surface in a dense repetitive array, HBV VLPs are capable of eliciting strong cellular and humoral immune responses whilst presenting no cytotoxicity in humans (Francis et al. 1990). Indeed in recent years there has been a great deal of interest in utilizing plant expressed HBV VLPs as carriers of immunogenic epitopes or peptides for vaccine development (Roose et al. 2013).

Human papillomavirus (HPV)

Researchers discovered that the expression of main capsid protein of HPV (L1) in enabled the formation of VLPs and consequently two commercial HPV L1based VLP vaccines, Gardasil ${ }^{\circledR}$ and Cervarix ${ }^{\mathrm{TM}}$, were produced in yeast and insect cells, respectively (Biemelt et al. 2003). However, the high cost of producing HPV VLPs in these expression system encouraged researchers to produce these VLPs in plants. At first, VLPs were produced by stable transgenic methods in potato and tobacco plants and were found to be similar in shape and size to commercially produced VLPs, but the yield was low. Transient expression with MagnICON vectors in N. benthamiana, however, increased the VLP yield to more acceptable levels (Chen and Lai 2013). HPV VLPs have also been produced in tobacco leaves using pEAQ vector (Matić et al. 2012). Studies have shown that plant-derived HPV VLPs are as effective as commercial vaccines in stimulating the immune system of animal models (Chen and Lai 2013). 
Table 1 Some companies using plant-based platform for pharmaceutical production

\begin{tabular}{|c|c|c|c|c|}
\hline Company & Host & Technology & Products & Websites \\
\hline Medicago & $\begin{array}{l}\text { Nicotiana } \\
\text { benthamiana }\end{array}$ & VLPExpress $^{\mathrm{TM}}$ & $\begin{array}{l}\text { Influenza VLP vaccine candidate; SARS- } \\
\text { CoV-2 VLP vaccine candidate }\end{array}$ & $\begin{array}{l}\text { https://www.medicago. } \\
\text { com/en/ }\end{array}$ \\
\hline Icon Genetics & $\begin{array}{l}\text { Nicotiana } \\
\text { benthamiana }\end{array}$ & $\begin{array}{r}\text { magnICON }^{\circledR} \text {-based } \\
\text { expression vector }\end{array}$ & $\begin{array}{l}\text { Vaccine candidate non-Hodgkin's } \\
\text { lymphoma; ZMapp }{ }^{\mathrm{TM}} \text { for Ebola virus } \\
\text { disease }\end{array}$ & $\begin{array}{l}\text { https://www. } \\
\text { icongenetics.com/ }\end{array}$ \\
\hline $\begin{array}{l}\text { Leaf Expression } \\
\text { Systems }\end{array}$ & $\begin{array}{l}\text { Nicotiana } \\
\text { benthamiana }\end{array}$ & $\begin{array}{l}\text { Hypertrans }{ }^{\circledR} \\
\text { Protein } \\
\text { Expression } \\
\text { System }\end{array}$ & $\begin{array}{l}\text { Cowpea Mosaic Virus VLPs; ecombinant } \\
\text { SARS-CoV N-protein (Nucleoprotein, } \\
\text { His-Tag); } \\
\text { SARS-CoV-2 Nucleocapsid (N) Protein }\end{array}$ & $\begin{array}{l}\text { https://www. } \\
\text { leafexpressionsystems. } \\
\text { com/ }\end{array}$ \\
\hline PlanetBiotechnology & $\begin{array}{c}\text { Tobacco } \\
\text { leaves }\end{array}$ & $\begin{array}{l}\text { Transient and } \\
\text { Stable Expression }\end{array}$ & CMG2-Fc; TEM8-Fc; BSG-Fc;AtCry1 & $\begin{array}{l}\text { https://www. } \\
\text { planetbiotechnology. } \\
\text { com/ }\end{array}$ \\
\hline Cape Bio Pharms & $\begin{array}{l}\text { Nicotiana } \\
\text { benthamiana }\end{array}$ & $\begin{array}{l}\text { Transient } \\
\text { Expression } \\
\text { Vector }\end{array}$ & $\begin{array}{l}\text { PtX }{ }^{\mathrm{TM}} \text { SARS-CoV-2 Spike Protein (S1, } \\
\text { Rabbit FC); PtX }{ }^{\mathrm{TM}} \text { SARS-CoV-2 Spike } \\
\text { Protein (RBD, Rabbit FC); CB_0002.5 } \\
\text { PtX }{ }^{\mathrm{TM}} \text { SARS-CoV-2 Spike Protein (S1- } \\
\text { His); Anti-HIV-1 p24 humanized IgG1 } \\
\text { antibody conjugated to Horseradish } \\
\text { Peroxidase (HRP); tX }{ }^{\mathrm{TM}} \text { Anti-HIV-1 } \\
\text { p24 Human IgG1 antibody }\end{array}$ & $\begin{array}{l}\text { https://www. } \\
\text { capebiopharms.com/ }\end{array}$ \\
\hline $\begin{array}{l}\text { Healthgen } \\
\text { Biotechnology }\end{array}$ & $\begin{array}{l}\text { Oryza sativa } \\
\text { (Rice) }\end{array}$ & Oryz ${ }^{\mathrm{HiExp}}$,platform & $\begin{array}{l}\text { Recombinant Human Serum Albumin } \\
\left(\text { OsrHSA }^{\mathrm{TM}}\right) \text {; Recombinant Epidermal } \\
\text { Growth Factor (OsrEGF) }\end{array}$ & $\begin{array}{l}\text { https://www.oryzogen. } \\
\text { net/ }\end{array}$ \\
\hline $\begin{array}{l}\text { Mapp } \\
\text { Biopharmaceutical }\end{array}$ & $\begin{array}{c}\text { Tobacco } \\
\text { leaves }\end{array}$ & $\begin{array}{l}\text { magnICON }^{\circledR}- \\
\text { Based Expression } \\
\text { Vector }\end{array}$ & $\mathrm{ZMapp}^{\mathrm{TM}}$ for Ebola virus disease & https://mappbio.com/ \\
\hline $\begin{array}{l}\text { Kentucky } \\
\text { BioProcessing }\end{array}$ & $\begin{array}{l}\text { Nicotiana } \\
\text { benthamiana }\end{array}$ & $\begin{array}{l}\text { magnICON }^{\circledR}- \\
\text { Based Expression } \\
\text { Vector }\end{array}$ & $\begin{array}{l}\mathrm{ZMapp}^{\mathrm{TM}} \text { Ebola virus disease; accine } \\
\text { candidate for SARS-CoV-2 (pre-clinical } \\
\text { phase) }\end{array}$ & $\begin{array}{l}\text { https:// } \\
\text { kentuckybioprocessing } \\
\text { com/ }\end{array}$ \\
\hline
\end{tabular}

$V L P$ Virus-like particle, $S A R S-C o V-2$ Severe acute respiratory syndrome coronavirus $2, I g G$ Immunoglobulin $\mathrm{G}$

Influenza virus

Influenza virus haemagglutinin protein (HA) when expressed in plant expression systems assembles into VLPs. Medicago has harnessed this technology to produce about ten million doses of VLP-based H1N1 Influenza vaccine in 1 month according to Phase I cGMP regulations (www.darpa.mil/NewsEvents/ Releases/2012/07/25.aspx). This company is currently the front runner worldwide in the production of plant-based influenza VLPs. Monovalent VLP-based vaccines were first developed and produced as a response to the $\mathrm{H} 7 \mathrm{~N} 9$ and $\mathrm{H} 5 \mathrm{~N} 1$ flu pandemics and were subsequently followed by the development of a plant-expressed quadrivalent HA-based VLP to fight seasonal flu, which has successfully completed the phase 1, 2, and 3 clinical trials (Pillet et al. 2016, 2019). Recently, two phase 3 trials have shown that plant-based HA VLPs provide better protection in adults against influenza viruses compared with commercial flu vaccines that derived from eggs (Ward et al. 2020). In addition, it has been shown that HAonly VLPs produced in plants afforded protection to participants in Phase I/II clinical trials while no negative effects on immune reactions or aggravation of plant-based allergies were observed due to plantderived glycosylation (Ward et al. 2014). Although, there has been much success achieved with the HA protein, other Influenza virus proteins such as M1 Matrix protein, NA neuraminidase, and the NP nucleoprotein remain to be explored as vaccine candidates due to their more conserved natures. 


\section{SARS-CoV-2}

Following the success of its production of influenza virus VLPs in plants, Medicago has, through its platform and acquired knowledge, developed a SARSCoV-2 VLP-based vaccine in plants, and is currently at the forefront of SARS-CoV-2 vaccine development. The SARS-CoV-2 spike gene sequence was introduced into $N$. benthamiana plants with agrobacteriummediated transformation. Following expression of the desired protein SARS-CoV-2 VLPs assembled which was quite similar in size and shape to the native SARSCoV-2 virions (Fig. 2) (Ward et al. 2021). This VLPbased SARS-CoV-2 vaccine candidate has shown to be successful in phase I human clinical trials and is currently undergoing phase 2 and 3 clinical trials and is estimated to be produced at a rate of 10 million doses per month (Rosales-Mendoza 2020; Phillip, International 2020).

\section{Chimeric plant-produced VLPs as vaccines}

VLPs may also act as a presentation system for the display of heterologous epitopes to the immune system. Foreign epitopes are coupled to the capsid proteins on the surface of VLPs either by genetic fusion or chemical conjugation and presented in high density repetitive arrays (Chen and Lai 2013). These chimeric VLPs (cVLPs) protect the presented antigen

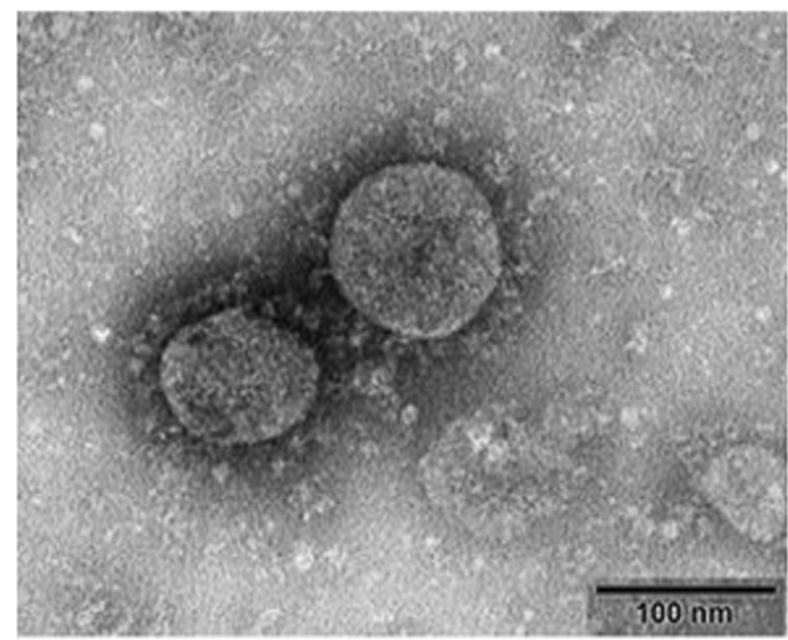

Fig. 2 Comparison of SARS-CoV-2 VLP made by Medicago with wild-type SARS-CoV-2 (Ward et al., 2021) https://www. medicago.com/en/). SARS-CoV-2 Severe acute respiratory and enhance immune cell uptake and stimulation due to their particulate nature and high density epitope presentation (Acosta-Ramírez et al. 2008; Lacasse et al. 2008; Manayani et al. 2007; Maurer et al. 2005; Plummer and Manchester 2011; Work et al. 2008). Although a more stable bond is generated between VLP and antigen via genetic fusion, it cannot be predicted with certainty whether chimeric VLPs will assemble properly, the assembly being dependent on factors such as peptide insert length and charge (Bendahmane et al. 1999). However a number of foreign epitopes have been successfully been inserted into domains of $\mathrm{HBcAg}$, HBsAg and HIV proteins that are dispensable for VLP assembly or fused to the $N$ - or $C$-termini of VLP capsid proteins (Chen and Lai 2013). In order to overcome the limitations of insert size and charge on the correct assembly of chimeric VLP, chemical conjugation of the target antigen to the native VLP is performed. Antigens are linked to the VLPs either through covalent bonds i.e. cysteinelysine linkages (Lechner et al. 2002) or noncovalent bonds i.e. streptavidin-biotin interaction (Chackerian et al. 2006). The specific interaction between Staphylococcus aureus protein A and the antibody constant fragment can also be exploited (Werner et al. 2006).

In the last two decades, HBcAg VLPs have been one of the most widely used platforms for the presentation of foreign antigens. The antigens of a number of pathogens such as foot-and-mouth-disease virus (FMDV), hepatitis $\mathrm{C}$ virus ( $\mathrm{HCV})$, hepatitis $\mathrm{B}$

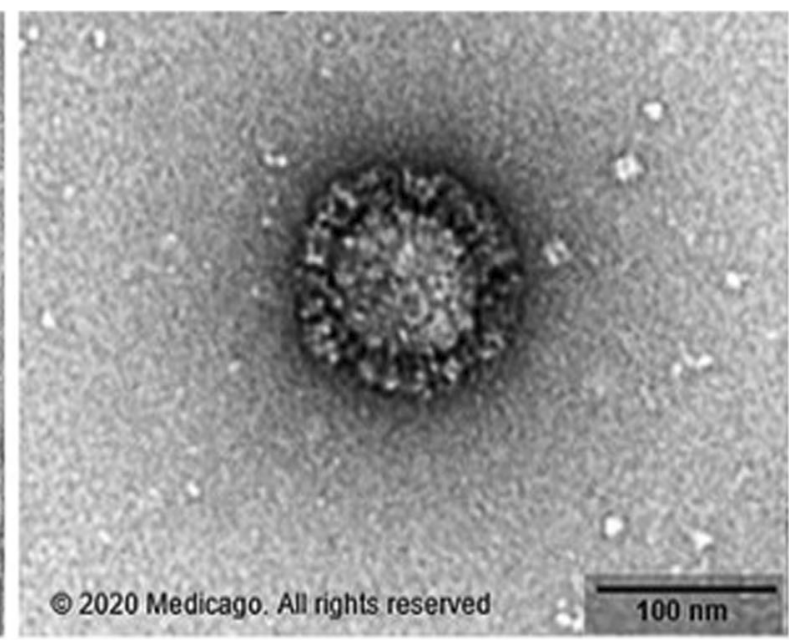

syndrome coronavirus 2, VLP Virus-like particle; (Left) Wildtype SARS-CoV-2; (Right) Medicago's Plant-Derived VLP of SARS-CoV-2 
virus (HBV), and HIV have been displayed using chimeric HBcAg VLPs (Chen and Li 2006; Clarke et al. 1987; Malik et al. 2012; Stahl and Murray 1989; Ulrich et al. 1992; Yang et al. 2005; Zhang et al. 2007; Zheng et al. 2016). Chimeric HBcAg VLPs presenting antigens from Dengue virus, Hepatitis E virus (HEV), Human papilloma virus (HPV), Influenza virus, malaria parasite, West Nile virus (WNV) and Zika virus have been expressed in plants (Buonaguro et al. 2011; Chen et al. 2011; Diamos et al. 2019, 2020; Pang et al. 2019; Ponndorf et al. 2021; Ravin et al. 2012; Santi et al. 2006; Yang et al. 2017; Zahmanova et al. 2021). Also produced in plants are chimeric hepatitis B surface antigen (HBsAg) VLPs presenting antigens from $\mathrm{HCV}$, HIV as well as the entire GFP protein (Greco et al. 2007; Huang and Mason 2004; Mohammadzadeh et al. 2020).

Another well researched epitope presentation platform are chimeric HPV VLPs (Lee et al. 2012; Schellenbacher et al. 2009; Slupetzky et al. 2001; Varsani et al. 2003). Chimeric HPV CLPs produced in plants have been used to display Influenza epitopes and HPV epitopes, amongst others (Chabeda et al. 2019; Rosa et al. 2009; Matić et al. 2011).

Plant virus particles (PVPs) offer similar advantages to VLPs in enhancing safety, immunogenicity, yield and stability of presented antigens (McCormick and Palmer 2008; Plummer and Manchester 2011; Sainsbury and Lomonossoff 2008). PVPs from Cowpea mosaic virus (CPMV), tobacco mosaic virus (TMV), cucumber mosaic virus (CMV), alfalfa mosaic virus, potato virus $\mathrm{X}$ (PVX), and papaya mosaic virus (PapMV) have been studied extensively (Brennan et al. 1999; Chichester et al. 2018; Attar et al. 2004; Jiang et al. 2006; Lacasse et al. 2008; Liu et al. 2005; Pulcini et al. 2013; Wang et al. 2007).

Plant-expressed chimeric Cucumber mosaic virus (CMV) PVPs have been used to present Newcastle disease virus epitopes as well as the Zika virus envelope protein (Cabral-Miranda et al. 2019; Natilla and Nemchinov 2008) while Papaya mosaic virus (PapMV) PVPs have displayed HCV and Influenza epitopes (Babin et al. 2013; Carignan et al. 2015; Denis et al. 2007; Laliberté-Gagné et al. 2019; Thérien et al. 2017). Plant expressed chimeric Cowpea mosaic virus (CPMV) PVPs have been used for the display of HIV epitopes (McLain et al., 1996) as well as more recently SARS-CoV-2 epitopes (Chung et al. 2020).
Formulating epitope-based vaccines is an option to reduce the risk of disease enhancement in SARS-CoV2 infection (Venkataraman et al. 2021).

\section{Conclusions and future perspective}

Virus-like particles (VLPs) have been shown to have a number of advantages over traditional and recombinant subunit vaccines including enhanced safety when compared to attenuated and inactivated vaccines and improved immunogenicity and stability when compared to subunit vaccines. When expressed in plant transient expression systems the additional advantages of VLPs include proper eukaryotic modification and assembly, high scalability for high yields, decreased cost for improved product accessibility to developing countries, increased safety due to the lack of contaminating human pathogens, as well as the production speed required to control the outbreak of pandemics, such as SARS-CoV-2.

Several pharmaceutical companies have specialized in producing plant pharmaceuticals and vaccines and efficient, scalable, cost-effective and cGMPcompliant processes have been developed to recover VLPs from plants (Chen and Lai 2013). Although the regulatory hurdle of FDA approval for plant-expressed VLPs still need to be overcome, the great strides accomplished by the plant-produced influenza and SARS-CoV-2 VLP-based vaccine candidates currently in Phase I, II and III clinical trials suggests that the registration of these products, and consequently acceptance of other plant-produced therapeutics and vaccines, is within reach.

Acknowledgements The authors would like to acknowledge the Plant Virology Research Center, Shiraz University, Shiraz, Iran.

Author contributions FH and MK: Writing the original draft; MH-D and SK: Reviewing and editing; AA and MHE: Reviewing; DR: Reviewing and English editing. All authors are in agreement with the content of the manuscript. The work described has not been submitted elsewhere for publication, and all the authors have approved the enclosed manuscript.

Funding This research received no specific grant from any funding agency in the public, commercial, or not-for-profit sectors. 


\section{Declarations}

Conflict of interest The authors have declared no conflict of interests.

Ethical approval This article does not contain any studies with animals performed by any of the authors.

\section{References}

Acosta-Ramírez E, Pérez-Flores R, Majeau N et al (2008) Translating innate response into long-lasting antibody response by the intrinsic antigen-adjuvant properties of papaya mosaic virus. Immunology 124(2):186-197

Armbruster N, Jasny E, Petsch B (2019) Advances in RNA vaccines for preventive indications: a case study of a vaccine against rabies. Vaccines 7(4):132

Babin C, Majeau N, Leclerc D (2013) Engineering of papaya mosaic virus (PapMV) nanoparticles with a CTL epitope derived from influenza NP. J Nanobiotechnol 11(1):1-8

Bachmann MF, Jennings GT (2010) Vaccine delivery: a matter of size, geometry, kinetics and molecular patterns. Nat Rev Immunol 10(11):787-796

Bachmann MF, Rohrer UH, Kundig TM et al (1993) The influence of antigen organization on B cell responsiveness. Science 262(5138):1448-1451

Bendahmane M, Koo M, Karrer E et al (1999) Display of epitopes on the surface of tobacco mosaic virus: impact of charge and isoelectric point of the epitope on virus-host interactions. J Mol Biol 290(1):9-20

Biemelt S, Sonnewald U, Galmbacher P et al (2003) Production of human papillomavirus type 16 virus-like particles in transgenic plants. J Virol 77(17):9211-9220

Brennan F, Jones T, Longstaff M et al (1999) Immunogenicity of peptides derived from a fibronectin-binding protein of $S$. aureus expressed on two different plant viruses. Vaccine 17(15-16):1846-1857

Buonaguro L, Tagliamonte M, Tornesello ML et al (2011) Developments in virus-like particle-based vaccines for infectious diseases and cancer. Expert Rev Vaccines 10(11):1569-1583

Cabral-Miranda G, Lim SM, Mohsen MO et al (2019) Zika virus-derived E-DIII protein displayed on immunologically optimized VLPs induces neutralizing antibodies without causing enhancement of dengue virus infection. Vaccines 7(3):72

Capell T, Twyman RM, Armario-Najera V et al (2020) Potential applications of plant biotechnology against SARS-CoV-2. Trends Plant Sci 25(7):635-643

Carignan D, Thérien A, Rioux G et al (2015) Engineering of the PapMV vaccine platform with a shortened M2e peptide leads to an effective one dose influenza vaccine. Vaccine 33(51):7245-7253

Castilho A, Pabst M, Leonard R et al (2008) Construction of a functional CMP-sialic acid biosynthesis pathway in Arabidopsis. Plant Physiol 147(1):331-339

Castilho A, Strasser R, Stadlmann J et al (2010) In planta protein sialylation through overexpression of the respective mammalian pathway. J Biol Chem 285(21):15923-15930
Castilho A, Gattinger P, Grass J et al (2011) N-glycosylation engineering of plants for the biosynthesis of glycoproteins with bisected and branched complex N-glycans. Glycobiology 21(6):813-823

Chabeda A, van Zyl AR, Rybicki EP et al (2019) Substitution of human papillomavirus type $16 \mathrm{~L} 2$ neutralizing epitopes into L1 surface loops: the effect on virus-like particle assembly and immunogenicity. Front Plant Sci 10:779

Chackerian B (2007) Virus-like particles: flexible platforms for vaccine development. Expert Rev Vaccines 6(3):381-390

Chackerian B, Rangel M, Hunter Z et al (2006) Virus and viruslike particle-based immunogens for Alzheimer's disease induce antibody responses against amyloid- $\beta$ without concomitant $\mathrm{T}$ cell responses. Vaccine 24(37-39):6321-6331

Chen Q (2008) Expression and purification of pharmaceutical proteins in plants. Biol Eng Trans 1(4):291-321

Chen Y, Guo D (2016) Molecular mechanisms of coronavirus RNA capping and methylation. Virol Sin 31(1):3-11

Chen Q, Lai H (2013) Plant-derived virus-like particles as vaccines. Hum Vaccin Immunother 9(1):26-49

Chen JY, Li F (2006) Development of hepatitis C virus vaccine using hepatitis B core antigen as immuno-carrier. World J Gastroenterol 12(48):7774

Chen Q, He J, Phoolcharoen W, Mason HS (2011) Geminiviral vectors based on bean yellow dwarf virus for production of vaccine antigens and monoclonal antibodies in plants. Hum Vaccin 7(3):331-338

Chichester JA, Green BJ, Jones RM et al (2018) Safety and immunogenicity of a plant-produced Pfs 25 virus-like particle as a transmission blocking vaccine against malaria: a phase 1 dose-escalation study in healthy adults. Vaccine 36(39):5865-5871

Chung YH, Cai H, Steinmetz NF (2020) Viral nanoparticles for drug delivery, imaging, immunotherapy, and theranostic applications. Adv Drug Deliv Rev 156:214-235

Clarke B, Newton S, Carroll A et al (1987) Improved immunogenicity of a peptide epitope after fusion to hepatitis B core protein. Nature 330(6146):381-384

Cox KM, Sterling JD, Regan JT et al (2006) Glycan optimization of a human monoclonal antibody in the aquatic plant Lemna minor. Nat Biotechnol 24(12):1591-1597

D'Aoust MA, Lavoie PO, Couture MMJ et al (2008) Influenza virus-like particles produced by transient expression in Nicotiana benthamiana induce a protective immune response against a lethal viral challenge in mice. Plant Biotechnol J 6(9):930-940

Davies HM (2010) Commercialization of whole-plant systems for biomanufacturing of protein products: evolution and prospects. Plant Biotechnol J 8(8):845-861

De la Rosa GP, Monroy-García A, de Lourdes M-G et al (2009) An HPV 16 L1-based chimeric human papilloma virus-like particles containing a string of epitopes produced in plants is able to elicit humoral and cytotoxic T-cell activity in mice. Virol J 6(1):1-11

Demain AL, Vaishnav P (2009) Production of recombinant proteins by microbes and higher organisms. Biotechnol Adv 27(3):297-306

Denis J, Majeau N, Acosta-Ramirez E et al (2007) Immunogenicity of papaya mosaic virus-like particles fused to a 
hepatitis $\mathrm{C}$ virus epitope: evidence for the critical function of multimerization. Virology 363(1):59-68

Diamos AG, Larios D, Brown L et al (2019) Vaccine synergy with virus-like particle and immune complex platforms for delivery of human papillomavirus L2 antigen. Vaccine 37(1):137-144

Diamos AG, Pardhe MD, Sun H et al (2020) Codelivery of improved immune complex and virus-like particle vaccines containing Zika virus envelope domain III synergistically enhances immunogenicity. Vaccine 38(18):3455-3463

Drosten C, Günther S, Preiser W et al (2003) Identification of a novel coronavirus in patients with severe acute respiratory syndrome. N Engl J Med 348(20):1967-1976

Du L, He Y, Zhou Y et al (2009) The spike protein of SARS$\mathrm{CoV}$ - a target for vaccine and therapeutic development. Nat Rev Microbiol 7(3):226-236

Edman JC, Hallewell RA, Valenzuela P et al (1981) Synthesis of hepatitis B surface and core antigens in E. coli. Nature 291(5815):503-506

El Attar A, Shamloul A, Shalaby A et al (2004) Expression of chimeric HCV peptide in transgenic tobacco plants infected with recombinant alfalfa mosaic virus for development of a plant-derived vaccine against $\mathrm{HCV}$. Afr J Biotech 3(11):588-594

Faye L, Gomord V (2010) Success stories in molecular farminga brief overview. Plant Biotechnol J. https://doi.org/10. 1111/j.1467-7652.2010.00521.x

Fehr AR, Perlman S (2015) Coronaviruses: an overview of their replication and pathogenesis Coronaviruses. Springer, New York, pp 1-23

Fehr T, Skrastina D, Pumpens P, Zinkernagel RM (1998) T cellindependent type I antibody response against B cell epitopes expressed repetitively on recombinant virus particles. Proc Natl Acad Sci 95(16):9477-9481

Folegatti PM, Ewer KJ, Aley PK et al (2020) Safety and immunogenicity of the ChAdOx 1 nCoV-19 vaccine against SARS-CoV-2: a preliminary report of a phase $1 / 2$, single-blind, randomised controlled trial. The Lancet 396(10249):467-478

Francis MJ, Hastings GZ, Brown AL et al (1990) Immunological properties of hepatitis B core antigen fusion proteins. Proc Natl Acad Sci 87(7):2545-2549

Fuenmayor J, Gòdia F, Cervera L (2017) Production of viruslike particles for vaccines. New Biotechnol 39:174-180

Funk CD, Laferrière C, Ardakani A (2021) Target product profile analysis of COVID-19 vaccines in phase III clinical trials and beyond: an early 2021 perspective. Viruses 13(3):418

Ge XY, Li JL, Yang XL et al (2013) Isolation and characterization of a bat SARS-like coronavirus that uses the ACE2 receptor. Nature 503(7477):535-538

Gecchele E, Merlin M, Brozzetti A et al (2015) A comparative analysis of recombinant protein expression in different biofactories: bacteria, insect cells and plant systems. $\mathbf{J}$ vis Exp 97:e52459

Giddings G (2001) Transgenic plants as protein factories. Curr Opin Biotechnol 12(5):450-454

Gomord V, Fitchette AC, Menu-Bouaouiche L et al (2010) Plant-specific glycosylation patterns in the context of therapeutic protein production. Plant Biotechnol J 8(5):564-587

Gralinski LE, Menachery VD (2020) Return of the coronavirus: 2019-nCoV. Viruses 12(2):135

Greco R, Michel M, Guetard D et al (2007) Production of recombinant HIV-1/HBV virus-like particles in Nicotiana tabacum and Arabidopsis thaliana plants for a bivalent plant-based vaccine. Vaccine 25(49):8228-8240

Grgacic EV, Anderson DA (2006) Virus-like particles: passport to immune recognition. Methods 40(1):60-65

Han Q, Lin Q, Jin S, You L (2020) Coronavirus 2019-nCoV: a brief perspective from the front line. $\mathrm{J}$ Infect 80(4):373-377

He Y, Jiang S (2005) Vaccine design for severe acute respiratory syndrome coronavirus. Viral Immunol 18(2):327-332

Hemida MG (2020) The middle east respiratory syndrome coronavirus (mers-cov) animal-origin viral zoonoses. Springer, Singapore, pp 241-254

Hemmati F, Saedi S, Hemmati-Dinarvand M et al (2020) Mysterious virus: a review on behavior and treatment approaches of the novel coronavirus, 2019-nCoV. Arch Med Res. https://doi.org/10.1016/j.arcmed.2020.04.022

Huang Z, Mason HS (2004) Conformational analysis of hepatitis B surface antigen fusions in an agrobacterium-mediated transient expression system. Plant Biotechnol J 2(3):241-249

Huang Z, Santi L, LePore K et al (2006) Rapid, high-level production of hepatitis $\mathrm{B}$ core antigen in plant leaf and its immunogenicity in mice. Vaccine 24(14):2506-2513

Huang Z, Chen Q, Hjelm B et al (2009) A DNA replicon system for rapid high-level production of virus-like particles in plants. Biotechnol Bioeng 103(4):706-714

Jiang L, Li Q, Li M et al (2006) A modified TMV-based vector facilitates the expression of longer foreign epitopes in tobacco. Vaccine 24(2):109-115

Ksiazek TG, Erdman D, Goldsmith CS et al (2003) A novel coronavirus associated with severe acute respiratory syndrome. N Engl J Med 348(20):1953-1966

Kushnir N, Streatfield SJ, Yusibov V (2012) Virus-like particles as a highly efficient vaccine platform: diversity of targets and production systems and advances in clinical development. Vaccine 31(1):58-83

Lacasse P, Denis J, Lapointe R et al (2008) Novel plant virusbased vaccine induces protective cytotoxic T-lymphocytemediated antiviral immunity through dendritic cell maturation. J Virol 82(2):785-794

Laliberté-Gagné MÈ, Bolduc M, Thérien A et al (2019) Increased immunogenicity of full-length protein antigens through sortase-mediated coupling on the PapMV vaccine platform. Vaccines 7(2):49

Lechner F, Jegerlehner A, Tissot AC et al (2002) Virus-like particles as a modular system for novel vaccines. Intervirology 45(4-6):212-217

Lee KW, Tey BT, Ho KL, Tan WS (2012) Delivery of chimeric hepatitis B core particles into liver cells. J Appl Microbiol 112(1):119-131

Li G, De Clercq E (2020) Therapeutic options for the 2019 novel coronavirus (2019-nCoV). Nature Publishing Group, Berlin

Li G, Fan Y, Lai Y et al (2020) Coronavirus infections and immune responses. J Med Virol 92(4):424-432 
Lico C, Chen Q, Santi L (2008) Viral vectors for production of recombinant proteins in plants. J Cell Physiol 216(2):366-377

Liu L, Cañizares MC, Monger W et al (2005) Cowpea mosaic virus-based systems for the production of antigens and antibodies in plants. Vaccine 23(15):1788-1792

Loh HS, Green BJ, Yusibov V (2017) Using transgenic plants and modified plant viruses for the development of treatments for human diseases. Curr Opin Virol 26:81-89

López-Macías C (2012) Virus-like particle (VLP)-based vaccines for pandemic influenza: performance of a VLP vaccine during the 2009 influenza pandemic. Hum Vaccines Immunother 8(3):411-414

Ma JK, Drake PM, Christou P (2003) The production of recombinant pharmaceutical proteins in plants. Nat Rev Genet 4(10):794-805

Ma JKC, Barros E, Bock R et al (2005) Molecular farming for new drugs and vaccines: current perspectives on the production of pharmaceuticals in transgenic plants. EMBO Rep 6(7):593-599

Mahmood N, Nasir SB, Hefferon K (2021) Plant-based drugs and vaccines for COVID-19. Vaccines 9(1):15

Malik IR, Chen A, Brass A et al (2012) A bi-functional hepatitis $\mathrm{B}$ virus core antigen $(\mathrm{HBcAg})$ chimera activates $\mathrm{HBcAg}-$ specific $\mathrm{T}$ cells and preS1-specific antibodies. Scand $\mathrm{J}$ Infect Dis 44(1):55-59

Malik YS, Sircar S, Bhat S et al (2020) Emerging novel coronavirus (2019-nCoV)—current scenario, evolutionary perspective based on genome analysis and recent developments. Vet Q 40(1):68-76

Manayani DJ, Thomas D, Dryden KA, Reddy V, Siladi ME, Marlett JM, Yeager M (2007) A viral nanoparticle with dual function as an anthrax antitoxin and vaccine. PLoS Pathog 3(10):e142

Marsian J, Lomonossoff GP (2016) Molecular pharmingVLPs made in plants. Curr Opin Biotechnol 37:201-206

Mason HS, Lam D, Arntzen CJ (1992) Expression of hepatitis B surface antigen in transgenic plants. Proc Natl Acad Sci 89(24):11745-11749

Mason HS, Ball JM, Shi JJ et al (1996) Expression of Norwalk virus capsid protein in transgenic tobacco and potato and its oral immunogenicity in mice. Proc Natl Acad Sci 93(11):5335-5340

Matić S, Rinaldi R, Masenga V, Noris E (2011) Efficient production of chimeric human papillomavirus $16 \mathrm{~L} 1$ protein bearing the M2e influenza epitope in Nicotiana benthamiana plants. BMC Biotechnol 11(1):1-12

Matić S, Masenga V, Poli A et al (2012) Comparative analysis of recombinant human papillomavirus $8 \mathrm{~L} 1$ production in plants by a variety of expression systems and purification methods. Plant Biotechnol J 10(4):410-421

Maurer P, Jennings GT, Willers J et al (2005) A therapeutic vaccine for nicotine dependence: preclinical efficacy, and phase I safety and immunogenicity. Eur J Immunol 35(7):2031-2040

McAleer W, Buynak E, Maigetter R et al (1992) Human hepatitis B vaccine from recombinant yeast. 1984. Biotechnology (reading, Mass) 24:500-502

McCormick AA, Palmer KE (2008) Genetically engineered tobacco mosaic virus as nanoparticle vaccines. Expert Rev Vaccines 7(1):33-41
McLain L, Durrani Z, Wisniewski LA et al (1996) Stimulation of neutralizing antibodies to human immunodeficiency virus type 1 in three strains of mice immunized with a 22 amino acid peptide of gp41 expressed on the surface of a plant virus. Vaccine 14(8):799-810

Mechtcheriakova I, Eldarov M, Nicholson L et al (2006) The use of viral vectors to produce hepatitis B virus core particles in plants. J Virol Methods 131(1):10-15

Meyers A, Chakauya E, Shephard E et al (2008) Expression of HIV-1 antigens in plants as potential subunit vaccines. BMC Biotechnol 8(1):53

Mohammadzadeh S, Roohvand F, Ehsani P et al (2020) Canola oilseed-and Escherichia coli-derived hepatitis C virus (HCV) core proteins adjuvanted with oil bodies, induced robust Th1-oriented immune responses in immunized mice. APMIS 128(11):593-602

Mulligan MJ, Lyke KE, Kitchin N et al (2020) Phase I/II study of COVID-19 RNA vaccine BNT162b1 in adults. Nature 586(7830):589-593

Natilla A, Nemchinov LG (2008) Improvement of PVX/CMV $\mathrm{CP}$ expression tool for display of short foreign antigens. Protein Expr Purif 59(1):117-121

Palca J (2020) Tobacco plants contribute key ingredient for COVID-19 Vaccine. https://www.npr.org/sections/healthshots/2020/10/15/923210562/tobacco-plants. Accessed 22 Dec 2020

Pan L, Zhang Y, Wang Y et al (2008) Foliar extracts from transgenic tomato plants expressing the structural polyprotein, P1-2A, and protease, 3C, from foot-andmouth disease virus elicit a protective response in guinea pigs. Vet Immunol Immunopathol 121(1-2):83-90

Pang EL, Peyret H, Ramirez A et al (2019) Epitope presentation of dengue viral envelope glycoprotein domain III on hepatitis B core protein virus-like particles produced in Nicotiana benthamiana. Front Plant Sci 10:455

Peyret H, Lomonossoff GP (2013) The pEAQ vector series: the easy and quick way to produce recombinant proteins in plants. Plant Mol Biol 83(1-2):51-58

Peyret H, Brown JK, Lomonossoff GP (2019) Improving plant transient expression through the rational design of synthetic $5^{\prime}$ and $3^{\prime}$ untranslated regions. Plant Methods 15(1): 108

Phillip M (2020) https://www.pmi.com/media-center/news/ pmi-announces. Accessed 25 Oct 2020

Pillet S, Aubin É, Trépanier S et al (2016) A plant-derived quadrivalent virus like particle influenza vaccine induces cross-reactive antibody and $\mathrm{T}$ cell response in healthy adults. Clin Immunol 168:72-87

Pillet S, Couillard J, Trépanier S et al (2019) Immunogenicity and safety of a quadrivalent plant-derived virus like particle influenza vaccine candidate-two randomized phase II clinical trials in 18 to 49 and $\geq 50$ years old adults. PLoS ONE 14(6): 0216533

Plummer EM, Manchester M (2011) Viral nanoparticles and virus-like particles: platforms for contemporary vaccine design. Wiley Interdiscip Rev 3(2):174-196

Ponndorf D, Meshcheriakova Y, Thuenemann EC et al (2021) Plant-made dengue virus-like particles produced by coexpression of structural and non-structural proteins induce a humoral immune response in mice. Plant Biotechnol J 19(4):745-756 
Pulcini C, Massin S, Launay O, Verger P (2013) Factors associated with vaccination for hepatitis $\mathrm{B}$, pertussis, seasonal and pandemic influenza among French general practitioners: a 2010 survey. Vaccine 31(37):3943-3949

Ravin N, Kotlyarov RY, Mardanova E et al (2012) Plant-produced recombinant influenza vaccine based on virus-like $\mathrm{HBc}$ particles carrying an extracellular domain of M2 protein. Biochem Mosc 77(1):33-40

Roldao A, Mellado MCM, Castilho LR et al (2010) Virus-like particles in vaccine development. Expert Rev Vaccines 9(10):1149-1176

Roose K, Baets SD, Schepens B, Saelens X (2013) Hepatitis B core-based virus-like particles to present heterologous epitopes. Expert Rev Vaccines 12(2):183-198

Rosales-Mendoza S (2020) Will plant-made biopharmaceuticals play a role in the fight against COVID-19? Expert Opin Biol Ther 20(6):545-548

Sainsbury F, Lomonossoff GP (2008) Extremely high-level and rapid transient protein production in plants without the use of viral replication. Plant Physiol 148(3):1212-1218

Salazar-González JA, Bañuelos-Hernández B, Rosales-Mendoza S (2015) Current status of viral expression systems in plants and perspectives for oral vaccines development. Plant Mol Biol 87(3):203-217

Saldaña S, Guadarrama FE, Flores TDJO et al (2006) Production of rotavirus-like particles in tomato (Lycopersicon esculentum L.) fruit by expression of capsid proteins VP2 and VP6 and immunological studies. Viral Immunol 19(1):42-53

Santi L, Huang Z, Mason H (2006) Virus-like particles production in green plants. Methods 40(1):66-76

Santi L, Batchelor L, Huang Z et al (2008) An efficient plant viral expression system generating orally immunogenic Norwalk virus-like particles. Vaccine 26(15):1846-1854

Santos MJD, Carrillo C, Ardila F et al (2005) Development of transgenic alfalfa plants containing the foot and mouth disease virus structural polyprotein gene P1 and its utilization as an experimental immunogen. Vaccine 23(15):1838-1843

Schähs M, Strasser R, Stadlmann J et al (2007) Production of a monoclonal antibody in plants with a humanized N-glycosylation pattern. Plant Biotechnol J 5(5):657-663

Schellenbacher C, Roden R, Kirnbauer R (2009) Chimeric L1L2 virus-like particles as potential broad-spectrum human papillomavirus vaccines. J Virol 83(19):10085-10095

Scotti N, Alagna F, Ferraiolo E et al (2009) High-level expression of the HIV-1 Pr55 gag polyprotein in transgenic tobacco chloroplasts. Planta 229(5):1109-1122

Slupetzky K, Shafti-Keramat S, Lenz P et al (2001) Chimeric papillomavirus-like particles expressing a foreign epitope on capsid surface loops. J Gen Virol 82(11):2799-2804

Song Z, Xu Y, Bao L et al (2019) From SARS to MERS, thrusting coronaviruses into the spotlight. Viruses 11(1):59

Stahl SJ, Murray K (1989) Immunogenicity of peptide fusions to hepatitis B virus core antigen. Proc Natl Acad Sci 86(16):6283-6287

Strasser R, Stadlmann J, Schähs M et al (2008) Generation of glyco-engineered Nicotiana benthamiana for the production of monoclonal antibodies with a homogeneous humanlike N-glycan structure. Plant Biotechnol J 6(4):392-402
Strasser R, Castilho A, Stadlmann J et al (2009) Improved virus neutralization by plant-produced anti-HIV antibodies with a homogeneous $\beta 1$, 4-galactosylated $\mathrm{N}$-glycan profile. J Biol Chem 284(31):20479-20485

Thanavala Y, Yang Y, Lyons P et al (1995) Immunogenicity of transgenic plant-derived hepatitis B surface antigen. Proc Natl Acad Sci 92(8):3358-3361

Thérien A, Bédard M, Carignan D et al (2017) A versatile papaya mosaic virus (PapMV) vaccine platform based on sortase-mediated antigen coupling. J Nanobiotechnol 15(1):1-13

Thuenemann CE, Lenzi P, Love JA et al (2013) The use of transient expression systems for the rapid production of virus-like particles in plants. Curr Pharm Des 19(31):5564-5573

Tschofen M, Knopp D, Hood E, Stöger E (2016) Plant molecular farming: much more than medicines. Annu Rev Anal Chem. https://doi.org/10.1146/annurev-anchem-071015041706

Twyman RM, Stoger E, Schillberg S et al (2003) Molecular farming in plants: host systems and expression technology. Trends Biotechnol 21(12):570-578

Ulrich R, Borisova G, Gren E et al (1992) Immunogenicity of recombinant core particles of hepatitis $\mathrm{B}$ virus containing epitopes of human immunodeficiency virus 1 core antigen. Adv Virol 126(1-4):321-328

Varsani A, Williamson AL, De Villiers D et al (2003) Chimeric human papillomavirus type 16 (HPV-16) L1 particles presenting the common neutralizing epitope for the L2 minor capsid protein of HPV-6 and HPV-16. J Virol 77(15):8386-8393

Venkataraman S, Hefferon K, Makhzoum A, Abouhaidar M (2021) Combating human viral diseases: will plant-based vaccines be the answer? Vaccines 9(7):761

Waheed MT, Gottschamel J, Hassan SW, Lössl AG (2012) Plant-derived vaccines: an approach for affordable vaccines against cervical cancer. Hum Vaccin Immunother 8(3):403-406

Wang LF, Shi Z, Zhang S et al (2006) Review of bats and SARS. Emerg Infect Dis 12(12):1834

Wang Y, Lü L, Weng S et al (2007) Molecular epidemiology and phylogenetic analysis of a marine fish infectious spleen and kidney necrosis virus-like (ISKNV-like) virus. Adv Virol 152(4):763-773

Ward BJ, Landry N, Trépanier S et al (2014) Human antibody response to $\mathrm{N}$-glycans present on plant-made influenza virus-like particle (VLP) vaccines. Vaccine 32(46):6098-6106

Ward BJ, Makarkov A, Séguin A et al (2020) Efficacy, immunogenicity, and safety of a plant-derived, quadrivalent, virus-like particle influenza vaccine in adults (18-64 years) and older adults ( $\geq 65$ years): two multicentre, randomised phase 3 trials. The Lancet 396(10261):1491-1503

Ward BJ, Gobeil P, Séguin A et al (2021) Phase 1 randomized trial of a plant-derived virus-like particle vaccine for COVID-19. Nat Med 27(6):1071-1078

Werner S, Marillonnet S, Hause G et al (2006) Immunoabsorbent nanoparticles based on a tobamovirus displaying protein A. Proc Natl Acad Sci 103(47):17678-17683 
Wildt S, Gerngross TU (2005) The humanization of N-glycosylation pathways in yeast. Nat Rev Microbiol 3(2):119-128

Williams TC, Burgers WA (2021) SARS-CoV-2 evolution and vaccines: cause for concern? Lancet Respir Med 9(4):333-335

Work TM, Aeby GS, Maragos JE (2008) Phase shift from a coral to a corallimorph-dominated reef associated with a shipwreck on Palmyra Atoll. PLoS ONE 3(8):e2989

Yang HJ, Chen M, Cheng T et al (2005) Expression and immunoactivity of chimeric particulate antigens of receptor binding site-core antigen of hepatitis B virus. World J Gastroenterol 11(4):492

Yang M, Lai H, Sun H, Chen Q (2017) Virus-like particles that display Zika virus envelope protein domain III induce potent neutralizing immune responses in mice. Sci Rep $7(1): 1-12$

Yao J, Weng Y, Dickey A, Wang KY (2015) Plants as factories for human pharmaceuticals: applications and challenges. Int J Mol Sci 16(12):28549-28565
Zahmanova G, Mazalovska M, Takova K et al (2021) Efficient production of chimeric hepatitis B virus-like particles bearing an epitope of hepatitis E virus capsid by transient expression in Nicotiana benthamiana. Life 11(1):64

Zhang YL, Guo YJ, Wang KY et al (2007) Enhanced immunogenicity of modified hepatitis B virus core particle fused with multiepitopes of foot-and-mouth disease virus. Scand J Immunol 65(4):320-328

Zheng D, Chen S, Qu D et al (2016) Influenza H7N9 LAH-HBc virus-like particle vaccine with adjuvant protects mice against homologous and heterologous influenza viruses. Vaccine 34(51):6464-6471

Zumla A, Chan JF, Azhar EI et al (2016) Coronaviruses-drug discovery and therapeutic options. Nat Rev Drug Discov 15(5):327-347

Publisher's Note Springer Nature remains neutral with regard to jurisdictional claims in published maps and institutional affiliations. 